\begin{tabular}{l} 
Bentham OPEN \\
CrossMark \\
\hline
\end{tabular}

\title{
Current and Future Techniques in Wound Healing Modulation after Glaucoma Filtering Surgeries
}

\author{
Masoumeh B. Masoumpour, ${ }^{1, *}$, M. Hossein Nowroozzadeh ${ }^{1}$ and M. Reza Razeghinejad ${ }^{1,2}$ \\ ${ }^{1}$ Poostchi Eye Research Center, Shiraz University of Medical Sciences, Shiraz, Iran \\ ${ }^{2}$ Truhlsen Eye Institute, University of Nebraska Medical Center, Omaha, USA
}

\begin{abstract}
Filtering surgeries are frequently used for controlling intraocular pressure in glaucoma patients. The long-term success of operation is intimately influenced by the process of wound healing at the site of surgery. Indeed, if has not been anticipated and managed accordingly, filtering surgery in high-risk patients could end up in bleb failure. Several strategies have been developed so far to overcome excessive scarring after filtering surgery. The principal step involves meticulous tissue handling and modification of surgical technique, which can minimize the severity of wound healing response at the first place. However, this is usually insufficient, especially in those with high-risk criteria. Thus, several adjuvants have been tried to stifle the exuberant scarring after filtration surgery. Conventionally, corticosteroids and anti-fibrotic agents (including 5-fluorouracil and Mitomycin-C) have been used for over three decades with semi-acceptable outcomes. Blebs and bleb associated complications are catastrophic side effects of anti-fibrotic agents, which occasionally are encountered in a subset of patients. Therefore, research continues to find a safer, yet effective adjuvant for filtering surgery. Recent efforts have primarily focused on selective inhibition of growth factors that promote scarring during wound healing process. Currently, only anti-VEGF agents have gained widespread acceptance to be translated into routine clinical practice. Robust evidence for other agents is still lacking and future confirmative studies are warranted. In this review, we explain the importance of wound healing process during filtering surgery, and describe the conventional as well as potential future adjuvants for filtration surgeries.
\end{abstract}

Keywords: Anti-fibrotics, filtering surgery, glaucoma, trabeculectomy, wound healing.

\section{INTRODUCTION}

Trabeculectomy and shunt surgeries are the two most common filtering operations performed on glaucomatous patients. The most widely performed procedure to reduce intraocular pressure (IOP) is trabeculectomy, which is used to create a channel between the anterior chamber of the eye and the subconjunctival space. This procedure allows the drainage of aqueous from the anterior chamber through the created channel into the subconjunctival space, thereby reducing IOP by a filtering bleb [1 - 3]. In shunt surgeries, the bleb is formed in the sub-Tenon's space around the plate of the shunt. Formation of a functioning filtering bleb is the cardinal sign of a successful filtering glaucoma surgery. An incomplete wound healing at the site of filtering surgery is necessary, which is against most other surgeries that complete healing and restoration of normal architecture of the incised tissue would be a preferred outcome.

The failure of glaucoma filtration surgery is usually due to excessive wound healing under the conjunctiva. This exuberant scarring and resultant obstruction is generally resulted from the healing response to the surgical injury. Therefore, wound healing suppression is necessary to prevent obstruction of the created channel. So far, many efforts have been made to control the process of wound healing and improve the outcome of filtering surgeries. The use of different groups of anti-fibrotic agents [5-fluorouracil (5-FU)] and Mitomycin C (MMC) has become a common practice to increase the success rates of filtering surgeries, and the advantages offered by these agents are accompanied by unique complications such as blebitis, endophthalmitis, late bleb leakage, and bleb dysesthesia [1,4]. Additionally,

\footnotetext{
* Address correspondence to this author at the Poostchi Eye Research Center, Poostchi Clinic, Zand Street, Shiraz 7134997446, Iran; Tel: +98-71-32302830; Fax: +98-71-32355936; Email: masoumpour@yahoo.com
} 
filtering blebs treated with these adjuvants may still fail via scarring, and due to their nonspecific mechanisms of action which causes widespread cell death and apoptosis. Herein, we review current wound healing modulators, surgical techniques, and potential novel therapeutic agents that may improve the outcomes of glaucoma filtering surgery.

\section{WOUND HEALING}

Healing pathway can be categorized into four main phases: coagulative, inflammatory, proliferative and remodeling. A variety of cells and biochemical factors are involved in the wound healing process. In the early stages, the process is controlled by immediate leakage of plasma proteins, blood cells, and platelets from the incised vasculature, along with release of local hormones such as prostaglandins, leukotrienes, histamine, and serotonin. In later steps of wound healing, activated platelets play a fundamental role via the release of a variety of chemicals and growth factors such as platelet activating factor, serotonin, thrombin, thromboxane $\mathrm{A}_{2}$, Platelet Derived Growth Factor (PDGF), connective tissue growth factor, Vascular Endothelial Growth Factor (VEGF), and insulin-like growth factor. Cytokines and chemokines including interleukin-1 (IL-1), IL-8, transforming growth factor (TGF- $\beta 1$ and $\beta 2$ ), and macrophage inflammatory protein are also secreted and serve as potent inflammatory chemo-attractants. At the same time, clotting factors are activated and the coagulation process progress via a complex cascade $[3,5]$.

The inflammatory phase is initiated through the influx of neutrophils. Monocytes differentiate into tissue macrophages that have essential effects on regulation of healing process. Growth factors that are released from tissue macrophages include TGF- $\beta$, PDGF, Fibroblast Growth Factor (FGF), and Epidermal Growth Factor (EGF). Another crucial inflammatory component, T-lymphocytes has a stimulatory action in early phase and down regulatory action in late phase of healing. Cytokines secreted from T-lymphocytes include TGF- $\beta$, PDGF, interferon- $\gamma$, and IL-4 [4, 6$]$.

In proliferative phase, proliferation of epithelial cells begins at the wound margin within a few hours after tissue injury. Together, angiogenesis and fibroplasia generate a new tissue matrix. Fibroblast is the principal cell type involved in this process. PDGF and TGF- $\beta$ are the two key profibrogenic cytokines implicated in the recruitment and activation of fibroblasts. Next, fibroblasts differentiate into myofibroblasts, which is a more contractile phenotype of these cell types. Angiogenesis typically begins soon after wound formation. Pro-angiogenic factors such as fibroblast growth factor and VEGF are released from platelets and macrophages. Later, this primitive fibrovascular tissue is evolved into a mature scar in the ultimate phase of wound healing. Extra Cellular Matrix (ECM) degradation is mediated by plasminogen activators and Matrix Metallo-proteinases (MMPs) via the removal of hyaluronan and fibronectin from the tissue. Fibroblast cell death by apoptosis is a fundamental event in remodeling phase $[3,5]$.

It is not fully elucidated why a particular patient ends up in bleb failure. Nevertheless, several risk factors have been introduced for failure of filtration surgery such as aphakia, younger age, ocular inflammation and neovascular glaucoma, ethnic origin, previous surgery, extended use of topical anti-glaucoma medications, and possibly diabetes [7 13]. The exact mechanisms by which the suggested predisposing factors can cause bleb failure are not fully understood. The detrimental effects of these factors may be mediated through the observed changes in the aqueous humour and intraocular environment $[14,15]$. Accordingly, it has been shown that the number of fibroblasts and inflammatory cells are changed in the conjunctiva of eyes with greater risk of failure [16, 17]. Cells and tissues around newly formed pathways are constantly bathed in the aqueous humour. Therefore, altered aqueous composition may play a crucial role in the results of filtration surgery [18].

\section{INTRAOPERATIVE WOUND HEALING MODULATION}

Intraoperative modulation of the wound healing that starts just after creating the wound is of utmost importance in controlling postoperative scarring. More meticulous surgical maneuvers, less traumatic tissue handling, and a better control of intraoperative bleeding minimize exuberant activity of wound healing process, but are usually insufficient for satisfactory prevention of scar formation [4]. Therefore, intraoperative adjuvants including anti-inflam-matory agents, anti-fibrotics, anti-VEGFs, and physical spa-cers have been used to achieve maximal control of post-operative wound healing $[3,5,19]$. In trabeculectomy, releasable sutures could also be used to manage the function of filtering bleb within a few weeks after surgery.

\section{Surgical Technique}

Simple changes in surgical technique have been introduced to enhance the bleb function and minimize bleb-related complications after filtering surgery. These modifications include single scleral punch sclerostomy, creating a large scleral flap not cut to the limbus, tight adjustable sutures, and a large treatment area with anti-fibrotics. These 
modifications allows aqueous to flow more posteriorly beneath the conjunctiva and consequently improves bleb function and morphology [20 - 22].

\section{Anti-Inflammatory Agents}

Glucocorticoids, as one of the most popular anti-inflammatory agents, are frequently used to blunt the healing process after glaucoma surgery $[5,19]$. They effectively alleviate postoperative inflammation and the resultant scarring that can end up in bleb failure [5, 23, 24]. Steroids modify the inflammatory process at several stages of the cascade of wound healing including reduction in concentration, migration, and activation of leukocytes, inhibition of growth factors secretion by macrophages, blunting the reaction of immune system to presented antigens, blocking transformation of membrane phospholipids to arachidonic acid, and reduction in vascular permeability [5].

Different steroidal agents have variable anti-inflammatory potency, IOP elevation properties, and ocular penetration (Fig. 1) [25]. These factors should be addressed when choosing any given steroid in glaucoma patients. For example, preparations with more lipid solubility are ideal for optimal tissue penetration and enhanced intraocular effect, while are less appropriate for local conjunctival effect, where less reduced penetration can increase conjunctival concen-tration $[5]$.
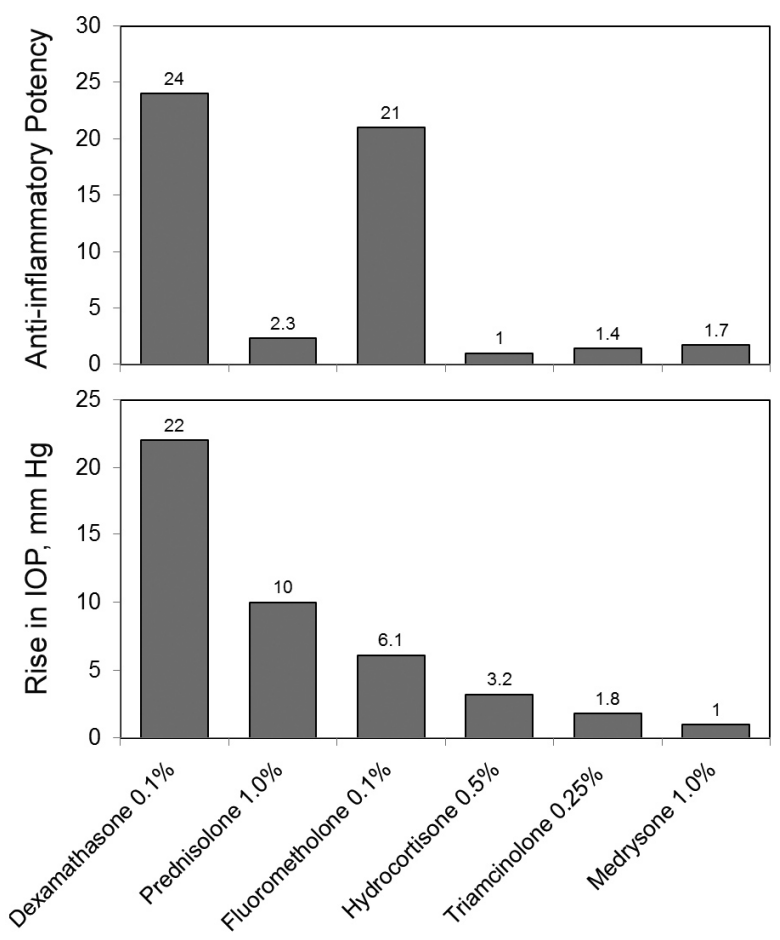

Type of Steroid

Fig. (1). Anti-inflammatory potency and IOP-elevating potential of different formulations of steroids.

The greatest IOP-elevation potency has been observed with dexamethasone $0.1 \%$ (22 $\mathrm{mmHg})$, followed by prednisolone acetate $1 \%$ (10), loteprednol etabonate $0.5 \%(9.2)$, and fluorometholone $0.1 \%(6.1)$ (Fig. 1) [25, 26]. In open-angle glaucoma, $46 \%-92 \%$ of patients may develop a steroid-induced IOP rise [27]. However, this prevalence decreases to $17-36 \%$ in operated glaucoma patients [28]. The proposed explanation is that in operated eyes a substantial amount of the aqueous bypasses the trabecular meshwork, the primary site of steroid-induced resistance, through the created track [19].

Beneficial effects of corticosteroids could be achieved through preoperative, intraoperative, or postoperative administration $[5,19]$. Intraoperative steroids may improve the outcome of glaucoma surgery [5, 23, 24]. Steroids could be administered through sub-Tenon, intrableb, intracameral, or retrobulbar injections [5, 19]. However, most studies evaluating intraoperative steroids have been retrospective and without a control group [23, 24]. Although the results of these studies seem promising, future well-designed studies should elucidate the most effective route, preparation, and 
dosage of intraoperative steroids application for glaucoma surgery.

\section{Anti-Fibrotic Agents}

Anti-fibrotic agents such as MMC and 5-FU prevent formation of scar through modification of fibroblast activity and proliferation. These agents have been used successfully as adjunctive therapy for glaucoma surgery over the past three decades. They are potent but carry risks of sight-threatening complications $[5,19]$.

\section{5-Fluorouracil}

The anti-proliferative property of 5-FU is mediated through interfering with pyrimidine metabolism [4, 29]. It inhibits DNA synthesis by inhibiting the synthesis of thymidine nucleotides, ending up in cell death [29]. It can effectively inhibit the fibroblast growth and has shown long-lasting effects on Tenon's fibroblasts [30]. Experimental studies on animals revealed that adjunctive 5-FU may prolong bleb survival through reduction in fibroblast proliferation and scarring [31].

Traditionally, 5-FU has been used promisingly as a regimen of several postoperative subconjunctival injections. However, the need for more postoperative examinations and the discomfort of frequent injections shifted the trend toward intraoperative direct sponge application of the drug [5, 19]. Currently, most surgeons prefer to use the drug intraoperatively, and postoperative injections are limited to those with imminent bleb failure [5, 19]. Previous clinical trials have established the role of adjunctive 5-FU in high-risk as well as low-risk glaucoma surgery candidates [32 36]. The most common reported complication is corneal epithelial toxicity and defect, pertaining to the fact that 5-FU is toxic to all replicating tissues $[32,37]$. Uveitis has also been reported more frequently in 5-FU treated eyes than controls [36]. As a trade-off for bleb survival, bleb leaks also occurs more frequently ( $9 \%$ in 5-FU and $2 \%$ in controls) [35].

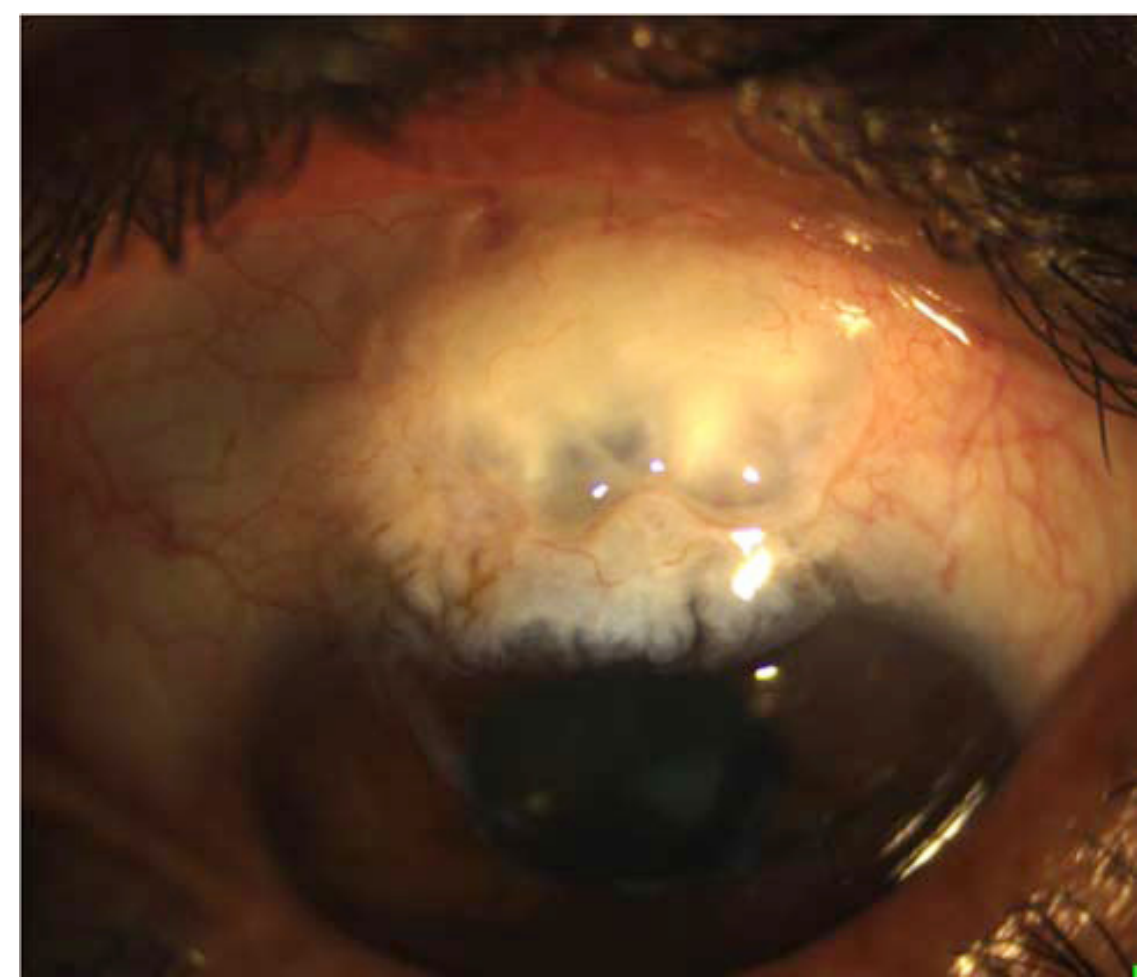

Fig. (2). Thin avascular bleb after trabeculectomy augmented with mitomycin.

\section{Mitomycin C}

MMC is activated via reduction into an alkylating agent, and then exerts its effect through DNA cross-linking. Besides inhibition of DNA replication, MMC can also interfere with mitosis and protein synthesis [4]. MMC can increase the success of glaucoma surgery via inhibition of fibroblast and endothelial cell proliferations [38]. Different 
aspects of MMC application including dosage, duration of application, and the extent of the treated surface can determine the outcome success [5]. It has been shown that intraoperative application of MMC for 2-2.5 minutes yields the same efficacy compared to more durable application (5 minutes) [39, 40]. However, MMC 0.002\% has shown less effectiveness compared with MMC 0.02\% [19, 41]. Eyes with larger area of application have more chance to achieve and maintain target IOP and experience less scarring of the bleb [19, 42 - 44]. Overall, MMC application leads to increased success of operation, lower target IOP, and a need for less medication to achieve target IOP [5, 19]. Its use is particularly promising in patients at high risk for failure (including combined cataract and glaucoma surgery, previous cataract surgery, or prior failed trabeculectomy), or those who require very low target IOP [5, 45].

In comparison to 5-FU, MMC is more potent and durable in inhibiting fibroblast proliferation [38, 46 - 48]. An experimental study showed that a single application of MMC induced prolonged growth inhibition for at least one month, whereas the inhibitory effect of 5-FU disappeared after 7 days [48]. Clinically, the MMC is more efficient than 5-FU in improving the surgical outcome and achieving target IOP, but is associated with higher rates of complications such as thin avascular blebs (Fig. 2), which carries the risk of hypotony and endophthalmitis [49 - 51]. The advantage of MMC over 5-FU has been more considerable in high-risk patients [52 - 54]; indeed, previous studies did not report significant differences in outcomes between the two medications for low-risk glaucoma surgery candidates [55, 56]. Important differences between 5-FU and MMC as an adjunct to filtering surgeries are summarized in Table $\mathbf{1 .}$

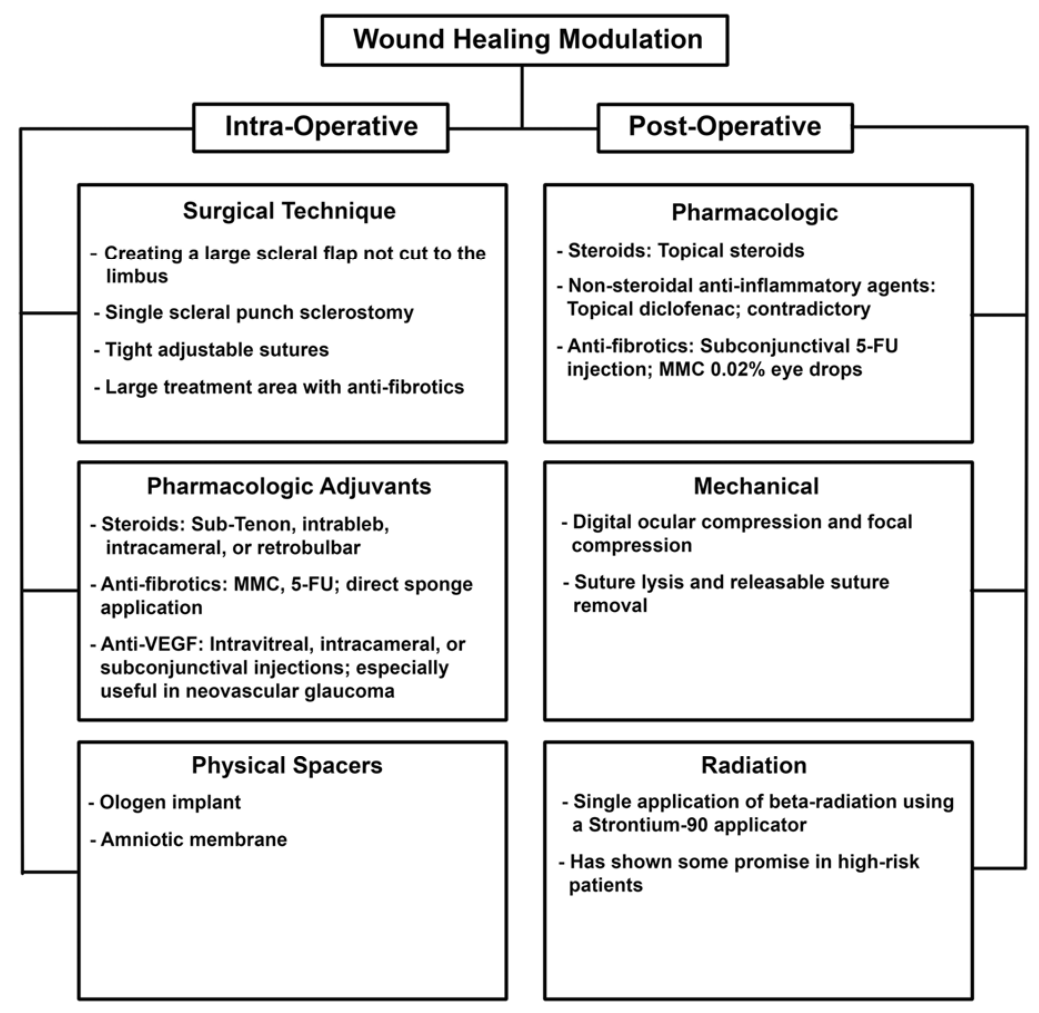

Fig. (3). A summary of current wound healing modulation techniques for trabeculectomy.

\section{Anti-VEGF Agents}

Besides its established role in angiogenesis, VEGFs also provokes the migration of fibroblasts and inflammatory cells [57]. In addition, VEGFs concentration in aqueous humor is considerably increased after glaucoma surgery [58, 59]. Based on these observations, anti-VEGFs may have potential anti-scarring properties in glaucoma surgery. Experimental and clinical studies have shown promising outcomes for anti-VEGF agents as an adjunct to filtering surgeries $[5,19,60]$. Some studies claimed an equal efficacy of anti-VEGF agents with that of 5-FU or MMC. Others suggested synergistic effects for combined application of anti-VEGF agents and 5-FU [61]. However, robust evidences about the efficacy of anti-VEGFs compared to anti-fibrotic agents are lacking and future confirmation through welldesigned studies is warranted. 
Due to widespread availability, nonspecific inhibition of all VEGF isoforms, and lower cost, bevacizumab was the most used agent in previous studies [5, 19]. It has been suggested that selective VEGF inhibitors such as pegaptanib (which inhibits $\mathrm{VEGF}_{165}$ ) may not be as effective as nonselective agents, because Tenon's fibroblast proliferation is mainly mediated via $\mathrm{VEGF}_{121}$ and $\mathrm{VEGF}_{189}$ isoforms that are not inhibited by pegaptanib [62]. Intraoperative bevacizumab can be delivered through intravitreal, intracameral, or subconjunctival injections. Subconjunctival injection of bevacizumab $(1.25 \mathrm{mg}$ or $2.5 \mathrm{mg})$ at the conclusion of surgery was the most popular rout of administration in previous reports $[5,19]$.

As an adjunct to glaucoma surgery, anti-VEGF agents are particularly promising in cases with neovascular glaucoma, where they may have additional advantages of reducing postoperative hyphema, and regression of angle neovascularization [5, 19,63-65]. If possible, intravitreal route should be considered in these conditions, because the drug remains more durably within ocular tissues and also directly treats the baseline pathology which usually resides in the retina (for example proliferative diabetic retinopathy or retinal vein occlusion) $[5,19,63,64]$. Intracameral route has the advantage of delivering substantial amount of anti-VEGF agent to both angle vessels and conjunctival bleb with a single injection.

Despite acceptable ocular safety profiles, there are concerns regarding systemic side effects of ocular anti-VEGFs therapy. These agents may marginally induce vascular attacks in susceptible patients. However, current literature is controversial regarding this issue, and further studies are warranted [66, 67]. Table 2 summarizes the advantages and disadvantages of each adjuvant class.

\section{Physical Spacers}

Spacers are biodegradable materials that are implanted beneath the conjunctiva during trabeculectomy. Besides their potential role as a reservoir for antiscarring agents, they mechanically separate conjunctiva from the episcleral surface for a while until resorption of implant, and hence prevent development of adhesions between the two surfaces [68, 69]. Ologen implant and amniotic membrane are among the most studied spacers.

The Ologen implant is a porcine-derived disc-shaped biodegradable collagen matrix, which has been used to inhibit exuberant scarring after trabeculectomy [69]. Several studies have compared its safety and efficacy with that of MMC; some reported equal efficacy [70 - 72], but others claimed inferior outcomes [73 - 75]. Current evidence is inadequate and well-designed trials are required before establishing its use as an adjunct to trabeculectomy [69].

A recent randomized controlled trial reports that the use of amniotic membrane in adjunct with trabeculectomy has been safe with IOP-lowering outcomes similar to that of MMC, and with less complications [76]. Moreover, addition of amniotic membrane transplantation to MMC application in trabeculectomy for refractory glaucoma cases showed lower postoperative average IOPs, greater success rates, and less complications compared to trabeculectomy with MMC alone [77].

\section{POSTOPERATIVE WOUND HEALING MODULATION}

Wound healing is a life-long process, and therefore a long-term modulation of healing process after operation is necessary to achieve optimal outcomes. The early postoperative period is the most important phase, and interventions to prevent imminent failure are usually performed at this stage [4]. Identification of the responsible causes of failure is essential for proper management. For example, if internal obstruction is not relived promptly, permanent adhesions between the conjunctiva and episclera can occur [78]. A variety of mechanical and pharmacological interventions have been applied postoperatively to prevent failure.

\section{Steroids and Non-Steroidal Anti-Inflammatory Agents}

Different routes, dosages, and duration of postoperative steroid therapy have been tried with variable effects. External signs of inflammation such as conjunctival injection may guide tapering the dosage of topical steroid [78]. In a randomized, prospective trial, Starita et al. [79] showed that success rates of glaucoma filtering surgeries were significantly improved with postoperative topical steroids but not with additional oral steroid. In two studies with 5 and 10 years of follow up after trabeculectomy the beneficial effects of topical steroids persisted in long-term [80, 81]. Reports regarding the possible beneficial effects of oral steroids are contradictory and current literature does not support using oral steroids in the perioperative period [80 - 82].

Non-steroidal Anti-inflammatory Agents (NSAIDs) act by inhibition of the cyclo-oxygenase enzyme and also 
inhibit platelet function and clot formation [5]. Gwin et al. [83] found no difference in IOP levels, bleb survival, or bleb morphology between the two groups of trabeculectomy in 28 rabbits treated postoperatively with either topical diclofenac or prednisolone acetate [83]. However, in a clinical trial on patients with trabeculectomy operation, no beneficial effects of diclofenac were observed compared to the prednisolone acetate in terms of the final follow up IOP, the number of anti-glaucoma medications, and adverse events [84]. The number of patients in this trial was limited to 26 and follow-up was too short (6 months). So, further evidence is needed to make a conclusion about the true role of NSAIDs after glaucoma filtration surgery [5].

Table 1. Comparison of 5-FU application vs MMC as adjunctive therapy for glaucoma surgery.

\begin{tabular}{|c|c|c|}
\hline & 5-Fluorouracil & Mitomycin C \\
\hline Composition [4] & Fluorinated pyrimidine analogue & $\begin{array}{l}\text { Antibiotic agent derived from the soil fungus } \\
\text { Streptomyces caespitosus } \\
\end{array}$ \\
\hline Mechanism of action $[4,18]$ & $\begin{array}{c}\text { Interferes with the synthesis of thymidine nucleotides } \\
\text { Inhibits DNA synthesis }\end{array}$ & $\begin{array}{c}\text { Cross-links DNA } \\
\text { Inhibits protein synthesis }\end{array}$ \\
\hline Target cells [37] & Fibroblasts & $\begin{array}{c}\text { Fibroblasts } \\
\text { Endothelial cells }\end{array}$ \\
\hline Potency $[4,45]$ & Less & More \\
\hline Durability [4, 45] & Less & More \\
\hline Application [4] & $\begin{array}{l}\text { Usually multiple postoperative injection } \\
\text { Intraoperative application }\end{array}$ & Single intraoperative application \\
\hline Use as adjunctive [44] & Less frequent $(7 \%)$ & More frequent $(68 \%)$ \\
\hline Bleb associated complications $[4 \mathrm{R}]^{\mathrm{a}}$ & Less & More \\
\hline Other side effects $[4,18]$ & $\begin{array}{c}\text { Corneal epithelial toxicity } \\
\text { Conjunctival erythema } \\
\text { Uveitis }\end{array}$ & $\begin{array}{c}\text { Scleritis } \\
\text { Scleromalacia } \\
\text { Corneal endothelial cell loss }\end{array}$ \\
\hline
\end{tabular}

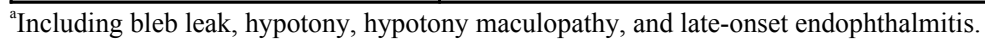

${ }^{\mathrm{b}}$ Intraoperative application decreases corneal complications by eliminating the need for postoperative injections.

\section{Radiation}

Single application of $\beta$-radiation has significant anti-proliferative effects on human Tenon's fibroblasts in vitro [85]. In contrast to anti-metabolites, fibroblast migration and contraction are not inhibited, but extracellular matrix production is altered [86]. The radiation is applied at the end of surgery using a self-sterilizing Strontium-90 applicator [87]. The main disadvantages of radiation are the possibility of keratopathy and cataract formation [5]. Clinical studies failed to show any benefit from radiation for IOP reduction after trabeculectomy in low-risk patients [88, 89], while radiation has shown some promise in high-risk groups [87].

\section{Digital Ocular Compression and Focal Compression}

Digital ocular compression can be applied to the inferior sclera or cornea and superior sclera posterior to the scleral flap through the lids [90]. To apply digital massage over the inferior cornea or sclera, the patient is asked to look up, and constant, moderate digital pressure is applied for 5 to 10 seconds. In the case of massage through superior eyelid posterior to scleral flap the patient is asked to look inferiorly. After digital massage the eye should be examined for potential complications, including corneal abrasions, hypotony, flat anterior chamber, hyphema, iris incarceration into the sclerostomy, and choroidal effusion or hemorrhage [90]. Ocular massage is suitable for patients who are physically capable of performing it and who had a beneficial response to the initial massage by the physician.

\section{Suture Lysis and Releasable Suture Removal}

Laser suture lysis or releasable suture removal in the early postoperative period can adjust the filtration flow in a controlled fashion [91 - 94]. Suture lysis and release of releasable sutures should be performed in a conservative stepwise manner. To avoid overfiltration and a flat anterior chamber removal or cutting of only one suture at a time is advised [95]. The timing of suture release is critical. In the case of surgery without anti-metabolites suture lysis or removal is performed within the first 2 weeks after surgery [78]. However, the golden time of effective intervention could be extended to several months after operation augmented with anti-fibrotics [96].

\section{Postoperative Anti-Fibrotics}

In cases of imminent filtration failure, subconjunctival 5-FU injection can enhance filtration and avoid failure [13, $33,34,97-106]$. The greatest beneficial effect of 5-FU injections seems to be in the first 18 months after surgery. A total 
dose of $105 \mathrm{mg}$, as described in Fluorouracil Filtering Surgery Study, is rarely given today. Lower yet effective doses are more convenient and associated with less pain and fewer complications [4, 35]. In a randomized clinical trial, Pakravan et al. [107] compared postoperative MMC $0.02 \%$ eye drops for 2 or 4 weeks with subconjunctival 5-FU injections for management of bleb failure and found comparable outcomes.

A summary of current wound healing modulation techniques for trabeculectomy is given in Fig. (3).

\section{POTENTIAL ANTI-SCARING AGENTS IN GLAUCOMA SURGERY}

The process of wound healing of glaucoma surgery depends on a delicate balance between proliferation, differentiation, motility, and apoptosis of cells involved in the repair process. A variety of growth factors are produced by the tissues at the site of surgery. The growth factors of aqueous humor and tear play a vital role in regulating these functions and consequently on the integrity of the wound at the site of surgery. Therefore, blocking the growth factors involved in the wound healing process may improve the success of the glaucoma filtering surgeries. The following are the suggested potential future anti-proliferative agents which may eventually be used instead of the current anti-mitotic agents.

\section{Transforming Growth Factor- $\beta$}

Transforming Growth Factor- $\beta$ is a cytokine with many roles in the immune system and plays a major role in the wound healing response and fibrosis. TGF- $\beta_{2}$ stimulates extracellular matrix formation, inhibits proteolytic enzymes, and mediates immunosuppression [44]. The level of TGF- $\beta$ in the aqueous humor of glaucoma patients has been found to be significantly higher than in that of normal individuals [108]. Release of TGF- $\beta$ by most cells including macrophages, sclera, conjunctiva and Tenon's cells causes fibroblast migration and proliferation and differentiation into myofibroblast and the synthesis of collagen. Among the three isoforms, the TGF- $\beta_{2}$ is the most common isoform found in the aqueous, and in the conjunctiva of scarred blebs [109, 110]. Different methods of inhibiting the profibrotic activity of TGF- $\beta$ as an anti-scarring therapy for glaucoma filtering surgery have been investigated.

\section{Monoclonal Antibodies}

TGF- $\beta_{2}$ monoclonal antibody (CAT-152 or lerdemi-mumab) selectively inhibits inflammatory factors that are released when the ocular tissues are damaged during surgery. It acts very specifically which is totally unlike to the more widespread effects of 5-FU and MMC. CAT-152 showed promising results with reduced scarring, and good bleb morphology in an animal study [111], but no significant effect on the bleb survival was observed in a randomized clinical trial on human subjects [112].

\section{Suramin}

Suramin is an anti-neoplastic and anti-parasitic agent that inhibits PDGF and FGF besides the TGF- $\beta$. In a human study, 10 glaucoma patients underwent trabeculectomy augmented with suramin and were compared with 10 other patients who received MMC, and 20 cases without MMC. At 18-month follow-up, suramin-treated eyes outcome was better compared to no anti-metabolite group and similar to MMC-treated eyes. It was as effective as MMC with regards to the time to failure of the trabeculectomy bleb and superior to the control group. Although the complications such as severe hypotony, choroidal detachments, and severe visual loss were less common in the Suramin group, because of the limited number of patients the safety profile could not be assessed [113].

\section{Tranilast}

Tranilast is an anti-allergic and anti-angiogenic agent which exerts its effects through its inhibitory effects on the release of histamine. It suppresses collagen synthesis by fibroblasts through inhibiting TGF- $\beta_{1}$, and other chemical mediators such as interleukin- $1_{b}$, and prostaglandin $E_{2}$ [114]. In a clinical trial, a total of 52 eyes of 52 patients received either saline or tranilast eye drops for 3 months after trabeculectomy. At 2 years, the tranilast group had significantly lower IOP than controls, with no differences in complications or adverse events. At the end of the first year, the tranilast group had a larger bleb area, along with a thicker, more vascularized bleb wall [115]. However, no other study has been put forward to validate these findings.

\section{Antisense Oligonucleotides}

An approach to target the TGF- $\beta$ signaling pathway is the use of microRNA (miRNA). MiRNAs bind to 
complementary mRNA and result in post transcription gene suppression [116]. Single-dose administration at the time of surgery in a mouse model of conjunctival scarring and a rabbit filtration surgery model reduced postoperative scarring [117]. There is no study on human with these agents.

Table 2. Comparison of 3 different classes of intraoperative adjunctive medications for glaucoma surgery.

\begin{tabular}{|c|c|c|c|}
\hline & Main Indication & Advantages & Disadvantages \\
\hline Sub-Tenon Steroids & Primary trabeculectomy & $\begin{array}{c}\text { Are available and inexpensive Reduce } \\
\text { postoperative inflammation }\end{array}$ & $\begin{array}{c}\text { May induce IOP rise in steroid-responders May not be } \\
\text { as effective as anti-fibrotics }\end{array}$ \\
\hline Anti-Fibrotics & $\begin{array}{c}\text { High-Risk patients Imminent } \\
\text { failure }\end{array}$ & $\begin{array}{c}\text { Associated with thin bleb and bleb-related } \\
\text { complications }\end{array}$ \\
\hline Anti-VEGF Agents & $\begin{array}{c}\text { Neovascular glaucoma Primary } \\
\text { trabeculectomy }\end{array}$ & $\begin{array}{c}\text { Maximum ocular safety Reduce } \\
\text { postoperative hyphema and } \\
\text { inflammation }\end{array}$ & $\begin{array}{c}\text { May induce systemic vascular attacks in susceptible } \\
\text { patients May promote avascular blebs }\end{array}$ \\
\hline
\end{tabular}

\section{Decorin}

Decorin is a naturally occurring TGF- $\beta$ inhibitor, useful in diminishing the conjunctival scarring response in surgery. The IOP at the second week in a rabbits who received subconjunctival decorin after trabeculectomy surgery was significantly lower and the histologic study also showed decreased extracellular matrix deposition. It appeared to have a clinically safe profile and in the biomicroscopic and histologic studies no sign of toxicity and inflammatory response were seen. The authors suggested that this naturally occurring compound may be potentially safer than monoclonal antibodies against TGF- $\beta$ because of immunologic reaction to CAT152 [118]. There is no human study on decorin.

\section{Signal Pathway Inhibition}

Inhibitions of TGF- $\beta$ receptor kinases and of downstream through which TGF- $\beta$ exerts its inflammatory and proliferative effects in wound healing are other potential therapeutic targets in glaucoma filtering surgery. Activation of TGF- $\beta_{2}$ receptor initiate the transcription machinery of the cell [119]. SB-431542 is a potent inhibitor of the TGF- $\beta_{1}$ receptor kinase, the ALK5. It showed an inhibitory effect on the differentiation of Tenon's fibroblast cells into myofibroblast. In vivo studies of low and high doses of this agent showed that its IOP lowering effect was greater than placebo, but not more than MMC [120].

\section{Lovastatin}

Lovastatin is a lipid lowering agent which blocks the effects of TGF- $\beta$ through interference of the Rho-signaling pathway [121]. The inhibitory effect of this agent on Tenon's fibroblast and collagen production suggests this agent as a safer, more specific target of wound modulation in glaucoma surgery. There is no study on these agents as adjuncts to filtering surgery.

\section{Pirfenidone}

Pirfenidone is an agent that has shown its anti-fibrotic potential in proliferation, migration, and collagen contraction of human Tenon's fibroblast. It exerts its downregulating effects on TGF- $\beta$ and a series of cytokines including Connective Tissue Growth Factor (CTGF), PDGF, and Tumor Necrosis Factor (TNF) [122]. In an animal study, the rabbits' eyes underwent trabeculectomy and received postoperative pirfenidone drops and the results were compared with the group that had trabeculectomy with and without MMC. Similar to MMC, pirfenidone, led to larger and higher blebs compared to control group and prolonged the bleb survival [123]. No trial has been conducted on humans to evaluate the effect of pirfenidone on glaucoma surgery.

\section{Rho-Associated Protein Kinase Inhibitor}

The Rho subfamily of small GTPases has major role in cell adhesion, motility, and migration. Rho-associated protein kinase I (ROCK I), has been identified as a Rho effecter. ROCKs regulate focal adhesions and stress fiber formation in cultured fibroblasts and epithelial cells. Topical Y-27632, an inhibitor of ROCK, reduced scar tissue formation in a rabbit model of glaucoma filtration surgery. Y-27632 exerts its effect through inhibiting transdifferentiation of human Tenon's fibroblasts into myofibroblasts [124]. 


\section{Matrix Metalloproteinase Inhibitors}

The MMPs are enzymes that degrade extracellular matrix, and their over-expression is associated with excessive scarring in the eye [125]. MMPs inhibitors have inhibitory effect collagen contraction, cell migration, and collagen production, at concentrations not associated with cellular toxicity [126]. In an experimental model of glaucoma surgery, the use of ilomastat (MMPs inhibitors) significantly reduced scar formation, with retention of normal tissue morphology. In other words, the effect was equivalent to MMC, but without the deleterious side effects of MMC [127, 128]. There is no data on these agents in human glaucoma surgery.

\section{Saratin}

Saratin prevents platelet adhesion and intimal hyperplasia in both animal and human models [129, 130]. The only in vivo study on saratin has been conducted on rabbits. The rabbits had glaucoma filtering surgery and received intraoperative topical saratin or intraoperative topical saratin plus two postoperative injections or MMC, and the results were compared with control group (balanced salt solution). Bleb elevation and survival in the group that received intraand postoperative saratin were comparable to $\mathrm{MMC}$, but without clinical toxicity. The intraoperative topical saratin alone did not improve bleb survival compared to controls. Saratin did not cause bleb avascularity and tissue thinning, which is a common finding in MMC treatment [131].

\section{Paclitaxel}

By stabilizing the microtubules of the mitotic spindle, paclitaxel, inhibits cell division and also decreases rates of restenosis after coronary stent implantation. It has promising effect in the treatment of malignant solid tumors such as ovarian, breast cancer, and non-small cell lung cancer [132]. In vitro studies revealed inhibitory effect of paclitaxel on the proliferation, migration, and collagen production of cultured human Tenon's fibroblasts [133]. Intraoperative subconjunctival application of the paclitaxel in an animal glaucoma filtering surgery revealed an effect comparable to intraoperative MMC [134]. No study on humans is available yet about the effect of paclitaxel on glaucoma filtering surgery.

\section{Placenta-Derived Growth Factor}

Placenta-derived Growth Factor (PIGF) is a major member of the VEGF family, which is a ligand for VEGF Receptor-1 (VEGFR-1) that enhances the angiogenic response of VEGF [135]. PIGF transcripts have been detected in placenta, heart, lung, thyroid gland and skeletal muscle. PIGF only acts on pathological angiogenesis [136] and inflammation [137], and has no role in physiological angiogenic processes. Previous results showed an upregulation of PlGF in aqueous humor of glaucoma patients [138, 139]. In a mouse model of trabeculectomy surgery, a single intracameral injection of anti-PIGF antibody increased bleb survival, bleb area, and also a significant reduction in postoperative proliferation, inflammation and angiogenesis during the first two postoperative weeks [139]. Sirulimus (rapamycin), a macrolide, reduces the response of inflammatory cells to certain cytokines and inhibits PIGF mediated fibroblast stimulation. In an in vivo study Sirulimus loaded films were able to prolong the success of filtering surgery [140].

\section{Caffeic Acid Phenethyl Ester}

Caffeic Acid Phenethyl Ester (CAPE) is a biologically active component of propolis from honeybee hives which has potent anti-inflammatory and antioxidant properties. It has been shown to reduce ocular inflammation and corneal vascularization $[141,142]$. The inhibitory effect of CAPE on inhibition of corneal neovascularization in an animal study on rats was comparable to that of topical dexamethasone. Regarding the major role of neovascularization on the wound healing CAPE may be a potential agent for modulating of the wound healing in glaucoma filtering surgeries [142]. Its anti-inflammatory and anti-proliferative effects might be mediated through inhibiting nuclear factor kappa B [143].

\section{CONCLUSION}

Glaucoma filtration surgery is an efficient and widely used surgery for patients with medically uncontrolled glaucoma. Unfortunately, scarring at the site of operation, which is the natural process of wound healing, can easily obstruct the filtration site and results in surgical failure. Although the mechanisms of scar tissue formation after filtering surgery are not fully understood, it is clear that excessive proliferation of Tenon's and conjunctival fibroblasts, differentiation of these fibroblasts into myofibroblasts, and uncontrolled production of extracellular matrix play a major 
role in the process. In order to modulate the healing process at the site of filtering surgery, the above-mentioned mechanisms should be targeted. MMC is still the most common anti-fibrotic agent used during filtering surgery in routine clinical practice. Although MMC is very effective in controlling the postoperative scarring, it causes widespread cell death and apoptosis, which may lead to vision-threatening complications. Therefore, we still need novel treatments in this regard. Such treatments will arise from a greater understanding of the associated biological processes and the modulators designed to manipulate their effect. None of the suggested wound healing modulators so far, has the capacity to arrive in clinical practice, except the anti-VEGFs, which are not as effective as MMC. Future methods of wound modulation may move towards genetic manipulation of cells involved in scar formation [144]. Someday we may be able to predict the risk of scar formation after glaucoma surgery in patients based on their own genetic profiles. The ultimate goal to be reached in the glaucoma filtering surgery is complete regeneration without scaring and visionthreatening side effects.

\section{CONFLICT OF INTEREST}

The authors confirm that this article content has no conflict of interest.

\section{ACKNOWLEDGEMENTS}

Declared none.

\section{REFERENCES}

[1] Razeghinejad MR, Fudemberg SJ, Spaeth GL. The changing conceptual basis of trabeculectomy: a review of past and current surgical techniques. Surv Ophthalmol 2012; 57(1): 1-25.

[http://dx.doi.org/10.1016/j.survophthal.2011.07.005] [PMID: 22137574]

[2] Coleman AL. Advances in glaucoma treatment and management: surgery. Invest Ophthalmol Vis Sci 2012; 53(5): 2491-4. [http://dx.doi.org/10.1167/iovs.12-94831] [PMID: 22562849]

[3] Atreides SP, Skuta GL, Reynolds AC. Wound healing modulation in glaucoma filtering surgery. Int Ophthalmol Clin 2004; $44(2)$ : 61-106. [http://dx.doi.org/10.1097/00004397-200404420-00007] [PMID: 15087731]

[4] Lama PJ, Fechtner RD. Antifibrotics and wound healing in glaucoma surgery. Surv Ophthalmol 2003; 48(3): $314-46$. [http://dx.doi.org/10.1016/S0039-6257(03)00038-9] [PMID: 12745005]

[5] Seibold LK, Sherwood MB, Kahook MY. Wound modulation after filtration surgery. Surv Ophthalmol 2012; 57(6): 530-50. [http://dx.doi.org/10.1016/j.survophthal.2012.01.008] [PMID: 23068975]

[6] Chang L, Crowston JG, Cordeiro MF, Akbar AN, Khaw PT. The role of the immune system in conjunctival wound healing after glaucoma surgery. Surv Ophthalmol 2000; 45(1): 49-68. [http://dx.doi.org/10.1016/S0039-6257(00)00135-1] [PMID: 10946081]

[7] Cunliffe IA, Richardson PS, Rees RC, Rennie IG. Effect of TNF, IL-1, and IL-6 on the proliferation of human Tenon's capsule fibroblasts in tissue culture. Br J Ophthalmol 1995; 79(6): 590-5.

[http://dx.doi.org/10.1136/bjo.79.6.590] [PMID: 7626577]

[8] Gross RL, Feldman RM, Spaeth GL, et al. Surgical therapy of chronic glaucoma in aphakia and pseudophakia. Ophthalmology 1988; 95(9): 1195-201.

[http://dx.doi.org/10.1016/S0161-6420(88)33027-7] [PMID: 3211498]

[9] Tomey KF, Traverso CE. The glaucomas in aphakia and pseudophakia. Surv Ophthalmol 1991; 36(2): 79-112. [http://dx.doi.org/10.1016/0039-6257(91)90124-X] [PMID: 1957248]

[10] Stürmer J, Broadway DC, Hitchings RA. Young patient trabeculectomy. Assessment of risk factors for failure. Ophthalmology 1993; 100(6): 928-39. [http://dx.doi.org/10.1016/S0161-6420(93)31552-6] [PMID: 8510908]

[11] Broadway D, Grierson I, Hitchings R. Racial differences in the results of glaucoma filtration surgery: are racial differences in the conjunctival cell profile important? Br J Ophthalmol 1994; 78(6): 466-75.

[http://dx.doi.org/10.1136/bjo.78.6.466] [PMID: 8060931]

[12] Broadway DC, Grierson I, Hitchings RA. Local effects of previous conjunctival incisional surgery and the subsequent outcome of filtration surgery. Am J Ophthalmol 1998; 125(6): 805-18. [http://dx.doi.org/10.1016/S0002-9394(98)00045-2] [PMID: 9645718]

[13] Fluorouracil Filtering Surgery Study one-year follow-up. Am J Ophthalmol 1989; 108(6): 625-35. [http://dx.doi.org/10.1016/0002-9394(89)90853-2] [PMID: 2688428]

[14] Lavin MJ, Wormald RP, Migdal CS, Hitchings RA. The influence of prior therapy on the success of trabeculectomy. Arch Ophthalmol 1990; 108(11): 1543-8.

[http://dx.doi.org/10.1001/archopht.1990.01070130045027] [PMID: 2244836] 
[15] Hugkulstone CE, Smith LF, Vernon SA. Trabeculectomy in diabetic patients with glaucoma. Eye (Lond) 1993; 7(Pt 4): 502-6. [http://dx.doi.org/10.1038/eye.1993.109] [PMID: 8253227]

[16] Broadway DC, Grierson I, O'Brien C, Hitchings RA. Adverse effects of topical antiglaucoma medication. II. The outcome of filtration surgery. Arch Ophthalmol 1994; 112(11): 1446-54.

[http://dx.doi.org/10.1001/archopht.1994.01090230060021] [PMID: 7980134]

[17] Sherwood MB, Grierson I, Millar L, Hitchings RA. Long-term morphologic effects of antiglaucoma drugs on the conjunctiva and Tenon's capsule in glaucomatous patients. Ophthalmology 1989; 96(3): 327-35. [http://dx.doi.org/10.1016/S0161-6420(89)32888-0] [PMID: 2710524]

[18] Yu DY, Morgan WH, Sun X, et al. The critical role of the conjunctiva in glaucoma filtration surgery. Prog Retin Eye Res 2009; 28(5): 303-28.

[http://dx.doi.org/10.1016/j.preteyeres.2009.06.004] [PMID: 19573620]

[19] Van Bergen T, Van de Velde S, Vandewalle E, Moons L, Stalmans I. Improving patient outcomes following glaucoma surgery: state of the art and future perspectives. Clin Ophthalmol 2014; 8: 857-67. [http://dx.doi.org/10.2147/OPTH.S48745] [PMID: 24833892]

[20] Georgoulas S, Dahlmann-Noor A, Brocchini S, Khaw PT. Modulation of wound healing during and after glaucoma surgery. Prog Brain Res 2008; 173: 237-54. [http://dx.doi.org/10.1016/S0079-6123(08)01117-5] [PMID: 18929113]

[21] Wells AP, Bunce C, Khaw PT. Flap and suture manipulation after trabeculectomy with adjustable sutures: titration of flow and intraocular pressure in guarded filtration surgery. J Glaucoma 2004; 13(5): 400-6. [http://dx.doi.org/10.1097/01.ijg.0000133387.82126.7c] [PMID: 15354079]

[22] Wells AP, Cordeiro MF, Bunce C, Khaw PT. Cystic bleb formation and related complications in limbus- versus fornix-based conjunctival flaps in pediatric and young adult trabeculectomy with mitomycin C. Ophthalmology 2003; 110(11): 2192-7. [http://dx.doi.org/10.1016/S0161-6420(03)00800-5] [PMID: 14597529]

[23] Kahook MY, Camejo L, Noecker RJ. Trabeculectomy with intraoperative retrobulbar triamcinolone acetonide. Clin Ophthalmol 2009; 3: 29-31. [PMID: 19668541]

[24] Tham CC, Li FC, Leung DY, et al. Intrableb triamcinolone acetonide injection after bleb-forming filtration surgery (trabeculectomy, phacotrabeculectomy, and trabeculectomy revision by needling): a pilot study. Eye (Lond) 2006; 20(12): 1484-6. [http://dx.doi.org/10.1038/sj.eye.6702372] [PMID: 16691258]

[25] Razeghinejad MR, Katz LJ. Steroid-induced iatrogenic glaucoma. Ophthalmic Res 2012; 47(2): 66-80. [http://dx.doi.org/10.1159/000328630] [PMID: 21757964]

[26] Rajpal RK, Digby D, D’Aversa G, Mah F, Hollander DA, Conway T. Intraocular pressure elevations with loteprednol etabonate: a retrospective chart review. J Ocul Pharmacol Ther 2011; 27(3): 305-8. [http://dx.doi.org/10.1089/jop.2010.0182] [PMID: 21574815]

[27] Tripathi RC, Parapuram SK, Tripathi BJ, Zhong Y, Chalam KV. Corticosteroids and glaucoma risk. Drugs Aging 1999; 15(6): 439-50. [http://dx.doi.org/10.2165/00002512-199915060-00004] [PMID: 10641955]

[28] Thomas R, Jay JL. Raised intraocular pressure with topical steroids after trabeculectomy. Graefes Arch Clin Exp Ophthalmol 1988; 226(4): 337-40. [http://dx.doi.org/10.1007/BF02172963] [PMID: 3169586]

[29] Skuta GL, Beeson CC, Higginbotham EJ, et al. Intraoperative mitomycin versus postoperative 5-fluorouracil in high-risk glaucoma filtering surgery. Ophthalmology 1992; 99(3): 438-44. [http://dx.doi.org/10.1016/S0161-6420(92)31951-7] [PMID: 1565457]

[30] Khaw PT, Sherwood MB, MacKay SL, Rossi MJ, Schultz G. Five-minute treatments with fluorouracil, floxuridine, and mitomycin have longterm effects on human Tenon's capsule fibroblasts. Arch Ophthalmol 1992; 110(8): 1150-4. [http://dx.doi.org/10.1001/archopht.1992.01080200130040] [PMID: 1386726]

[31] Gressel MG, Parrish RK II, Folberg R. 5-fluorouracil and glaucoma filtering surgery: I. An animal model. Ophthalmology 1984; 91(4): $378-83$. [http://dx.doi.org/10.1016/S0161-6420(84)34277-4] [PMID: 6717922]

[32] Heuer DK, Parrish RK II, Gressel MG, Hodapp E, Palmberg PF, Anderson DR. 5-fluorouracil and glaucoma filtering surgery. II. A pilot study. Ophthalmology 1984; 91(4): 384-94. [http://dx.doi.org/10.1016/S0161-6420(84)34291-9] [PMID: 6201793]

[33] Goldenfeld M, Krupin T, Ruderman JM, et al. 5-Fluorouracil in initial trabeculectomy. A prospective, randomized, multicenter study. Ophthalmology 1994; 101(6): 1024-9. [http://dx.doi.org/10.1016/S0161-6420(94)31223-1] [PMID: 8008342]

[34] Ophir A, Ticho U. A randomized study of trabeculectomy and subconjunctival administration of fluorouracil in primary glaucomas. Arch Ophthalmol 1992; 110(8): 1072-5. [http://dx.doi.org/10.1001/archopht.1992.01080200052023] [PMID: 1497518] 
[35] Five-year follow-up of the Fluorouracil Filtering Surgery Study. Am J Ophthalmol 1996; 121(4): 349-66. [http://dx.doi.org/10.1016/S0002-9394(14)70431-3] [PMID: 8604728]

[36] Wong TT, Khaw PT, Aung T, et al. The singapore 5-Fluorouracil trabeculectomy study: effects on intraocular pressure control and disease progression at 3 years. Ophthalmology $2009 ; 116(2): 175-84$ [http://dx.doi.org/10.1016/j.ophtha.2008.09.049] [PMID: 19187822]

[37] Shapiro MS, Thoft RA, Friend J, Parrish RK, Gressel MG. 5-Fluorouracil toxicity to the ocular surface epithelium. Invest Ophthalmol Vis Sci 1985; 26(4): 580-3. [PMID: 3980172]

[38] Smith S, D’Amore PA, Dreyer EB. Comparative toxicity of mitomycin C and 5-fluorouracil in vitro. Am J Ophthalmol 1994; 118 (3): 332-7. [http://dx.doi.org/10.1016/S0002-9394(14)72957-5] [PMID: 8085590]

[39] Mégevand GS, Salmon JF, Scholtz RP, Murray AD. The effect of reducing the exposure time of mitomycin C in glaucoma filtering surgery. Ophthalmology 1995; 102(1): 84-90. [http://dx.doi.org/10.1016/S0161-6420(95)31049-4] [PMID: 7831047]

[40] Schnyder CC, Bernasconi O, Mermoud A, Faggioni R. [Comparative study of administration time of mitomycin C in trabeculectomy: 2.5 or 5 minutes?]. Klin Monatsbl Augenheilkd 1995; 206(5): 307-11. [http://dx.doi.org/10.1055/s-2008-1035448] [PMID: 7609372]

[41] Thornton I, Xu M, Krueger RR. Comparison of standard $(0.02 \%)$ and low dose $(0.002 \%)$ mitomycin C in the prevention of corneal haze following surface ablation for myopia. J Refract Surg 2008; 24(1): S68-76. [PMID: 18269154]

[42] Matlach J, Panidou E, Grehn F, Klink T. Large-area versus small-area application of mitomycin C during trabeculectomy. Eur J Ophthalmol 2013; 23(5): 670-7.

[http://dx.doi.org/10.5301/ejo.5000287] [PMID: 23640510]

[43] Onol M, Aktaş Z, Hasanreisoğlu B. Enhancement of the success rate in trabeculectomy: large-area mitomycin-C application. Clin Experimen Ophthalmol 2008; 36(4): 316-22.

[http://dx.doi.org/10.1111/j.1442-9071.2008.01736.x] [PMID: 18700917]

[44] Khaw PT, Chang L, Wong TT, Mead A, Daniels JT, Cordeiro MF. Modulation of wound healing after glaucoma surgery. Curr Opin Ophthalmol 2001; 12(2): 143-8 [http://dx.doi.org/10.1097/00055735-200104000-00011] [PMID: 11224722]

[45] Joshi AB, Parrish RK II, Feuer WF. 2002 survey of the American Glaucoma Society: practice preferences for glaucoma surgery and antifibrotic use. J Glaucoma 2005; 14(2): 172-4. [http://dx.doi.org/10.1097/01.ijg.0000151684.12033.4d] [PMID: 15741822]

[46] Jampel HD. Effect of brief exposure to mitomycin C on viability and proliferation of cultured human Tenon's capsule fibroblasts. Ophthalmology 1992; 99(9): 1471-6. [http://dx.doi.org/10.1016/S0161-6420(92)31781-6] [PMID: 1407982]

[47] Khaw PT, Sherwood MB, Doyle JW, et al. Intraoperative and post operative treatment with 5-fluorouracil and mitomycin-c: long term effects in vivo on subconjunctival and scleral fibroblasts. Int Ophthalmol 1992; 16(4-5): 381-5. [http://dx.doi.org/10.1007/BF00917996] [PMID: 1428576]

[48] Khaw PT, Doyle JW, Sherwood MB, Grierson I, Schultz G, McGorray S. Prolonged localized tissue effects from 5-minute exposures to fluorouracil and mitomycin C. Arch Ophthalmol 1993; 111(2): 263-7. [http://dx.doi.org/10.1001/archopht.1993.01090020117035] [PMID: 8431167]

[49] Sisto D, Vetrugno M, Trabucco T, Cantatore F, Ruggeri G, Sborgia C. The role of antimetabolites in filtration surgery for neovascular glaucoma: intermediate-term follow-up. Acta Ophthalmol Scand 2007; 85(3): 267-71. [http://dx.doi.org/10.1111/j.1600-0420.2006.00810.x] [PMID: 17488455]

[50] Greenfield DS, Liebmann JM, Jee J, Ritch R. Late-onset bleb leaks after glaucoma filtering surgery. Arch Ophthalmol 1998; $116(4)$ : $443-7$. [http://dx.doi.org/10.1001/archopht.116.4.443] [PMID: 9565040]

[51] Higginbotham EJ, Stevens RK, Musch DC, et al. Bleb-related endophthalmitis after trabeculectomy with mitomycin C. Ophthalmology 1996; 103(4): 650-6. [http://dx.doi.org/10.1016/S0161-6420(96)30639-8] [PMID: 8618766]

[52] Katz GJ, Higginbotham EJ, Lichter PR, et al. Mitomycin C versus 5-fluorouracil in high-risk glaucoma filtering surgery. Extended follow-up. Ophthalmology 1995; 102(9): 1263-9.

[http://dx.doi.org/10.1016/S0161-6420(95)30874-3] [PMID: 9097762]

[53] Kim HY, Egbert PR, Singh K. Long-term comparison of primary trabeculectomy with 5-fluorouracil versus mitomycin C in West Africa. J Glaucoma 2008; 17(7): 578-83 [http://dx.doi.org/10.1097/IJG.0b013e31816b304a] [PMID: 18854737]

[54] Lamping KA, Belkin JK. 5-Fluorouracil and mitomycin C in pseudophakic patients. Ophthalmology 1995; 102(1): 70-5. [http://dx.doi.org/10.1016/S0161-6420(95)31051-2] [PMID: 7831045] 
[55] Palanca-Capistrano AM, Hall J, Cantor LB, Morgan L, Hoop J, WuDunn D. Long-term outcomes of intraoperative 5-fluorouracil versus intraoperative mitomycin $\mathrm{C}$ in primary trabeculectomy surgery. Ophthalmology 2009; 116(2): 185-90. [http://dx.doi.org/10.1016/j.ophtha.2008.08.009] [PMID: 18930550]

[56] Singh K, Mehta K, Shaikh NM, et al. Trabeculectomy with intraoperative mitomycin C versus 5-fluorouracil. Prospective randomized clinical trial. Ophthalmology 2000; 107(12): 2305-9. [http://dx.doi.org/10.1016/S0161-6420(00)00391-2] [PMID: 11097613]

[57] Bao P, Kodra A, Tomic-Canic M, Golinko MS, Ehrlich HP, Brem H. The role of vascular endothelial growth factor in wound healing. J Surg Res 2009; 153(2): 347-58

[http://dx.doi.org/10.1016/j.jss.2008.04.023] [PMID: 19027922]

[58] Asahara T, Bauters C, Zheng LP, et al. Synergistic effect of vascular endothelial growth factor and basic fibroblast growth factor on angiogenesis in vivo. Circulation 1995; 92(9 Suppl.): II365-71. [http://dx.doi.org/10.1161/01.CIR.92.9.365] [PMID: 7586439]

[59] Li Z, Van Bergen T, Van de Veire S, et al. Inhibition of vascular endothelial growth factor reduces scar formation after glaucoma filtration surgery. Invest Ophthalmol Vis Sci 2009; 50(11): 5217-25. [http://dx.doi.org/10.1167/iovs.08-2662] [PMID: 19474408]

[60] Vandewalle E, Abegão Pinto L, Van Bergen T, et al. Intracameral bevacizumab as an adjunct to trabeculectomy: a 1-year prospective, randomised study. Br J Ophthalmol 2014; 98(1): 73-8. [http://dx.doi.org/10.1136/bjophthalmol-2013-303966] [PMID: 24158846]

[61] How A, Chua JL, Charlton A, et al. Combined treatment with bevacizumab and 5-fluorouracil attenuates the postoperative scarring response after experimental glaucoma filtration surgery. Invest Ophthalmol Vis Sci 2010; 51(2): 928-32. [http://dx.doi.org/10.1167/iovs.09-3949] [PMID: 19797222]

[62] Van Bergen T, Vandewalle E, Van de Veire S, et al. The role of different VEGF isoforms in scar formation after glaucoma filtration surgery. Exp Eye Res 2011; 93(5): 689-99.

[http://dx.doi.org/10.1016/j.exer.2011.08.016] [PMID: 21907194]

[63] Cornish KS, Ramamurthi S, Saidkasimova S, Ramaesh K. Intravitreal bevacizumab and augmented trabeculectomy for neovascular glaucoma in young diabetic patients. Eye (Lond) 2009; 23(4): 979-81. [http://dx.doi.org/10.1038/eye.2008.113] [PMID: 18451875]

[64] Horsley MB, Kahook MY. Anti-VEGF therapy for glaucoma. Curr Opin Ophthalmol 2010; 21(2): 112-7. [http://dx.doi.org/10.1097/ICU.0b013e3283360aad] [PMID: 20040875]

[65] Yazdani S, Hendi K, Pakravan M, Mahdavi M, Yaseri M. Intravitreal bevacizumab for neovascular glaucoma: a randomized controlled trial. J Glaucoma 2009; 18(8): 632-7. [http://dx.doi.org/10.1097/IJG.0b013e3181997211] [PMID: 19826393]

[66] Campbell RJ, Gill SS, Bronskill SE, Paterson JM, Whitehead M, Bell CM. Adverse events with intravitreal injection of vascular endothelial growth factor inhibitors: nested case-control study. BMJ 2012; 345: e4203. [http://dx.doi.org/10.1136/bmj.e4203] [PMID: 22763393]

[67] Kemp A, Preen DB, Morlet N, et al. Myocardial infarction after intravitreal vascular endothelial growth factor inhibitors: a whole population study. Retina 2013; 33(5): 920-7.

[http://dx.doi.org/10.1097/IAE.0b013e318276e07b] [PMID: 23492942]

[68] Rosentreter A, Mellein AC, Konen WW, Dietlein TS. Capsule excision and Ologen implantation for revision after glaucoma drainage device surgery. Graefes Arch Klin Exp Ophthalmol 2010; 248(9): 1319-24. [http://dx.doi.org/10.1007/s00417-010-1385-y]

[69] He M, Wang W, Zhang X, Huang W. Ologen implant versus mitomycin C for trabeculectomy: a systematic review and meta-analysis. PLoS One 2014; 9(1): e85782.

[http://dx.doi.org/10.1371/journal.pone.0085782] [PMID: 24465704]

[70] Senthil S, Rao HL, Babu JG, Mandal AK, Garudadri CS. Comparison of outcomes of trabeculectomy with mitomycin C vs. ologen implant in primary glaucoma. Indian J Ophthalmol 2013; 61(7): 338-42. [http://dx.doi.org/10.4103/0301-4738.109520] [PMID: 23571259]

[71] Marey HM, Mandour SS, Ellakwa AF. Subscleral trabeculectomy with mitomycin-C versus ologen for treatment of glaucoma. J Ocul Pharmacol Ther 2013; 29(3): 330-4. [http://dx.doi.org/10.1089/jop.2012.0120] [PMID: 23113645]

[72] Cillino S, Di Pace F, Cillino G, Casuccio A. Biodegradable collagen matrix implant vs mitomycin-C as an adjuvant in trabeculectomy: a 24month, randomized clinical trial. Eye (Lond) 2011; 25(12): 1598-606. [http://dx.doi.org/10.1038/eye.2011.219] [PMID: 21921953]

[73] Narayanaswamy A, Perera SA, Htoon HM, et al. Efficacy and safety of collagen matrix implants in phacotrabeculectomy and comparison with mitomycin $\mathrm{C}$ augmented phacotrabeculectomy at 1 year. Clin Experiment Ophthalmol 2013; 41(6): 552-60. [http://dx.doi.org/10.1111/ceo.12058] [PMID: 23279607]

[74] Papaconstantinou D, Georgalas I, Karmiris E, et al. Trabeculectomy with OloGen versus trabeculectomy for the treatment of glaucoma: a 
pilot study. Acta Ophthalmol 2010; 88(1): 80-5.

[http://dx.doi.org/10.1111/j.1755-3768.2009.01753.x] [PMID: 19900209]

[75] Rosentreter A, Schild AM, Jordan JF, Krieglstein GK, Dietlein TS. A prospective randomised trial of trabeculectomy using mitomycin C vs an ologen implant in open angle glaucoma. Eye (Lond) 2010; 24(9): 1449-57. [http://dx.doi.org/10.1038/eye.2010.106] [PMID: 20733558]

[76] Khairy HA, Elsawy MF. Trabeculectomy with mitomycin-c versus trabeculectomy with amniotic membrane transplant: a medium-term randomized, controlled trial. J Glaucoma 2015; 24(7): 556-9. [PMID: 24844538]

[77] Sheha H, Kheirkhah A, Taha H. Amniotic membrane transplantation in trabeculectomy with mitomycin C for refractory glaucoma. J Glaucoma 2008; 17(4): 303-7.

[http://dx.doi.org/10.1097/IJG.0b013e31815c3a47] [PMID: 18552616]

[78] Azuara-Blanco A, Katz LJ. Dysfunctional filtering blebs. Surv Ophthalmol 1998; 43(2): 93-126. [http://dx.doi.org/10.1016/S0039-6257(98)00025-3] [PMID: 9763136]

[79] Starita RJ, Fellman RL, Spaeth GL, Poryzees EM, Greenidge KC, Traverso CE. Short- and long-term effects of postoperative corticosteroids on trabeculectomy. Ophthalmology 1985; 92(7): 938-46. [http://dx.doi.org/10.1016/S0161-6420(85)33931-3] [PMID: 4022581]

[80] Araujo SV, Spaeth GL, Roth SM, Starita RJ. A ten-year follow-up on a prospective, randomized trial of postoperative corticosteroids after trabeculectomy. Ophthalmology 1995; 102(12): 1753-9. [http://dx.doi.org/10.1016/S0161-6420(95)30797-X] [PMID: 9098274]

[81] Roth SM, Spaeth GL, Starita RJ, Birbillis EM, Steinmann WC. The effects of postoperative corticosteroids on trabeculectomy and the clinical course of glaucoma: five-year follow-up study. Ophthalmic Surg 1991; 22(12): 724-9. [PMID: 1787937]

[82] Azuara-Blanco A, Spaeth GL, Augsburger JJ. Oral prednisone in guarded filtration procedures supplemented with antimetabolites. Ophthalmic Surg Lasers 1999; 30(2): 126-32. [PMID: 10037207]

[83] Gwin TD, Stewart WC, Gwynn DR. Filtration surgery in rabbits treated with diclofenac or prednisolone acetate. Ophthalmic Surg 1994; 25(4): $245-50$. [PMID: 8015778$]$

[84] Kent AR, Dubiner HB, Whitaker R, et al. The efficacy and safety of diclofenac $0.1 \%$ versus prednisolone acetate $1 \%$ following trabeculectomy with adjunctive mitomycin-C. Ophthalmic Surg Lasers 1998; 29(7): 562-9. [PMID: 9674006]

[85] Constable PH, Crowston JG, Occleston NL, Cordeiro MF, Khaw PT. Long term growth arrest of human Tenon's fibroblasts following single applications of beta radiation. Br J Ophthalmol 1998; 82(4): 448-52. [http://dx.doi.org/10.1136/bjo.82.4.448] [PMID: 9640199]

[86] Constable PH, Crowston JG, Occleston NL, Khaw PT. The effects of single doses of beta radiation on the wound healing behaviour of human Tenon's capsule fibroblasts. Br J Ophthalmol 2004; 88(2): 169-73. [http://dx.doi.org/10.1136/bjo.2003.020388] [PMID: 14736764]

[87] Kirwan JF, Cousens S, Venter L, et al. Effect of beta radiation on success of glaucoma drainage surgery in South Africa: randomised controlled trial. BMJ 2006; 333(7575): 942. [http://dx.doi.org/10.1136/bmj.38971.395301.7C] [PMID: 17023435]

[88] Rehman SU, Amoaku WM, Doran RM, Menage MJ, Morrell AJ. Randomized controlled clinical trial of beta irradiation as an adjunct to trabeculectomy in open-angle glaucoma. Ophthalmology 2002; 109(2): 302-6. [http://dx.doi.org/10.1016/S0161-6420(01)00885-5] [PMID: 11825813]

[89] Barnes RM, Mora JS, Best SJ. Beta radiation as an adjunct to low-risk trabeculectomy. Clin Experiment Ophthalmol 2000; $28(4)$ : 259-62. [http://dx.doi.org/10.1046/j.1442-9071.2000.00317.x] [PMID: 11021553]

[90] Wieland M, Spaeth GL. Use of digital compression following glaucoma surgery. Ophthalmic Surg 1988; 19(5): 350-2. [PMID: 3399263]

[91] Zeiter JH, Corder DM, Swendris RP, Parrow KA. Early postoperative titration of bleb function: argon laser suture lysis and removable sutures in trabeculectomy. J Glaucoma 1992; 1(4): 291. [http://dx.doi.org/10.1097/00061198-199201040-00017] [PMID: 18079663]

[92] Hoskins HD Jr, Migliazzo C. Management of failing filtering blebs with the Argon laser. Ophthalmic Surg 1984; 15(9): 731-3. [PMID: 6493678]

[93] Melamed S, Ashkenazi I, Glovinski J, Blumenthal M. Tight scleral flap trabeculectomy with postoperative laser suture lysis. Am J Ophthalmol 1990; 109(3): 303-9. [http://dx.doi.org/10.1016/S0002-9394(14)74555-6] [PMID: 2400418]

[94] Savage JA, Condon GP, Lytle RA, Simmons RJ. Laser suture lysis after trabeculectomy. Ophthalmology 1988; 95(12): 1631-8. [http://dx.doi.org/10.1016/S0161-6420(88)32964-7] [PMID: 3068601] 
[95] Geijssen HC, Greve EL. Mitomycine, suterelysis and hypotony. Int Ophthalmol 1992; 16(4-5): 371-4. [http://dx.doi.org/10.1007/BF00917994] [PMID: 1428574]

[96] Pappa KS, Derick RJ, Weber PA, Kapetansky FM, Baker ND, Lehmann DM. Late argon laser suture lysis after mitomycin C trabeculectomy. Ophthalmology 1993; 100(8): 1268-71.

[http://dx.doi.org/10.1016/S0161-6420(93)31494-6] [PMID: 8341513]

[97] Three-year follow-up of the Fluorouracil Filtering Surgery Study. Am J Ophthalmol 1993; 115(1): 82-92. [http://dx.doi.org/10.1016/S0002-9394(14)73529-9] [PMID: 8420383]

[98] Liebmann JM, Ritch R, Marmor M, Nunez J, Wolner B. Initial 5-fluorouracil trabeculectomy in uncomplicated glaucoma. Ophthalmology 1991; 98(7): 1036-41. [http://dx.doi.org/10.1016/S0161-6420(91)32180-8] [PMID: 1891210]

[99] Rockwood EJ, Parrish RK II, Heuer DK, et al. Glaucoma filtering surgery with 5-fluorouracil. Ophthalmology 1987; 94(9): 1071-8. [http://dx.doi.org/10.1016/S0161-6420(87)33321-4] [PMID: 3684224]

[100] Ticho U, Ophir A. Regulating the dose of 5-fluorouracil to prevent filtering bleb scarring. Ann Ophthalmol 1991; 23(6): 225-9. [PMID: 1746816]

[101] Weinreb RN. Adjusting the dose of 5-fluorouracil after filtration surgery to minimize side effects. Ophthalmology 1987; 94(5): 564-70. [http://dx.doi.org/10.1016/S0161-6420(87)33430-X] [PMID: 2439972]

[102] Araie M, Shoji N, Shirato S, Nakano Y. Postoperative subconjunctival 5-fluorouracil injections and success probability of trabeculectomy in Japanese: results of 5-year follow-up. Jpn J Ophthalmol 1992; 36(2): 158-68. [PMID: 1513063]

[103] Ren J, Shin DH, O'Grady JM, et al. Long-term outcome of primary glaucoma triple procedure with adjunctive 5-fluorouracil. Graefes Arch Clin Exp Ophthalmol 1998; 236(7): 501-6. [http://dx.doi.org/10.1007/s004170050112] [PMID: 9672795]

[104] Tsai JC, Feuer WJ, Parrish RK II, Grajewski AL. 5-Fluorouracil filtering surgery and neovascular glaucoma. Long-term follow-up of the original pilot study. Ophthalmology 1995; 102(6): 887-92. [http://dx.doi.org/10.1016/S0161-6420(95)30938-4] [PMID: 7777295]

[105] Rothman RF, Liebmann JM, Ritch R. Low-dose 5-fluorouracil trabeculectomy as initial surgery in uncomplicated glaucoma: long-term followup. Ophthalmology 2000; 107(6): 1184-90. [http://dx.doi.org/10.1016/S0161-6420(00)00085-3] [PMID: 10857841]

[106] Ruderman JM, Welch DB, Smith MF, Shoch DE. A randomized study of 5-fluorouracil and filtration surgery. Am J Ophthalmol 1987; 104(3): 218-24 [http://dx.doi.org/10.1016/0002-9394(87)90407-7] [PMID: 3631181]

[107] Pakravan M, Miraftabi A, Yazdani S, Koohestani N, Yaseri M. Topical mitomycin-c versus subconjunctival 5-fluorouracil for management of bleb failure. J Ophthalmic Vis Res 2011; 6(2): 78-86. [PMID: 22454715]

[108] Tripathi RC, Li J, Chan WF, Tripathi BJ. Aqueous humor in glaucomatous eyes contains an increased level of TGF-beta 2. Exp Eye Res 1994; 59(6): 723-7. [http://dx.doi.org/10.1006/exer.1994.1158] [PMID: 7698265]

[109] Cordeiro MF. Role of transforming growth factor beta in conjunctival scarring. Clin Sci 2003; 104(2): 181-7. [http://dx.doi.org/10.1042/cs1040181] [PMID: 12546640]

[110] Cordeiro MF, Gay JA, Khaw PT. Human anti-transforming growth factor-beta2 antibody: a new glaucoma anti-scarring agent. Invest Ophthalmol Vis Sci 1999; 40(10): 2225-34. [PMID: 10476787]

[111] Mead AL, Wong TT, Cordeiro MF, Anderson IK, Khaw PT. Evaluation of anti-TGF-beta2 antibody as a new postoperative anti-scarring agent in glaucoma surgery. Invest Ophthalmol Vis Sci 2003; 44(8): 3394-401. [http://dx.doi.org/10.1167/iovs.02-0978] [PMID: 12882787]

[112] Khaw P, Grehn F, Holló G, et al. A phase III study of subconjunctival human anti-transforming growth factor beta(2) monoclonal antibody (CAT-152) to prevent scarring after first-time trabeculectomy. Ophthalmology 2007; 114(10): 1822-30. [http://dx.doi.org/10.1016/j.ophtha.2007.03.050] [PMID: 17908591]

[113] Mietz H, Krieglstein GK. Suramin to enhance glaucoma filtering procedures: a clinical comparison with mitomycin. Ophthalmic Surg Lasers 2001; 32(5): 358-69. [PMID: 11563779]

[114] Suzawa H, Kikuchi S, Ichikawa K, Koda A. Inhibitory action of tranilast, an anti-allergic drug, on the release of cytokines and PGE2 from human monocytes-macrophages. Jpn J Pharmacol 1992; 60(2): 85-90. [http://dx.doi.org/10.1254/jjp.60.85] [PMID: 1282575]

[115] Chihara E, Dong J, Ochiai H, Hamada S. Effects of tranilast on filtering blebs: a pilot study. J Glaucoma 2002; 11(2): 127-33. [http://dx.doi.org/10.1097/00061198-200204000-00008] [PMID: 11912360] 
[116] Jinek M, Doudna JA. A three-dimensional view of the molecular machinery of RNA interference. Nature 2009; 457(7228): 405-12. [http://dx.doi.org/10.1038/nature07755] [PMID: 19158786]

[117] Cordeiro MF, Mead A, Ali RR, et al. Novel antisense oligonucleotides targeting TGF-beta inhibit in vivo scarring and improve surgical outcome. Gene Ther 2003; 10(1): 59-71.

[http://dx.doi.org/10.1038/sj.gt.3301865] [PMID: 12525838]

[118] Grisanti S, Szurman P, Warga M, et al. Decorin modulates wound healing in experimental glaucoma filtration surgery: a pilot study. Invest Ophthalmol Vis Sci 2005; 46(1): 191-6. [http://dx.doi.org/10.1167/iovs.04-0902] [PMID: 15623773]

[119] Zi Z, Chapnick DA, Liu X. Dynamics of TGF- $\beta /$ Smad signaling. FEBS Lett 2012; 586(14): 1921-8. [http://dx.doi.org/10.1016/j.febslet.2012.03.063] [PMID: 22710166]

[120] Xiao YQ, Liu K, Shen JF, Xu GT, Ye W. SB-431542 inhibition of scar formation after filtration surgery and its potential mechanism. Invest Ophthalmol Vis Sci 2009; 50(4): 1698-706. [http://dx.doi.org/10.1167/iovs.08-1675] [PMID: 19098325]

[121] Meyer-Ter-Vehn T, Katzenberger B, Han H, Grehn F, Schlunck G. Lovastatin inhibits TGF-beta-induced myofibroblast transdifferentiation in human tenon fibroblasts. Invest Ophthalmol Vis Sci 2008; 49(9): 3955-60. [http://dx.doi.org/10.1167/iovs.07-1610] [PMID: 18421080]

[122] Lin X, Yu M, Wu K, Yuan H, Zhong H. Effects of pirfenidone on proliferation, migration, and collagen contraction of human Tenon's fibroblasts in vitro. Invest Ophthalmol Vis Sci 2009; 50(8): 3763-70. [http://dx.doi.org/10.1167/iovs.08-2815] [PMID: 19264889]

[123] Zhong H, Sun G, Lin X, Wu K, Yu M. Evaluation of pirfenidone as a new postoperative antiscarring agent in experimental glaucoma surgery. Invest Ophthalmol Vis Sci 2011; 52(6): 3136-42. [http://dx.doi.org/10.1167/iovs.10-6240] [PMID: 21330661]

[124] Honjo M, Tanihara H, Kameda T, Kawaji T, Yoshimura N, Araie M. Potential role of Rho-associated protein kinase inhibitor Y-27632 in glaucoma filtration surgery. Invest Ophthalmol Vis Sci 2007; 48(12): 5549-57. [http://dx.doi.org/10.1167/iovs.07-0878] [PMID: 18055804]

[125] Li DQ, Lee SB, Gunja-Smith Z, et al. Overexpression of collagenase (MMP-1) and stromelysin (MMP-3) by pterygium head fibroblasts. Arch Ophthalmol 2001; 119(1): 71-80. [PMID: 11146729]

[126] Daniels JT, Cambrey AD, Occleston NL, et al. Matrix metalloproteinase inhibition modulates fibroblast-mediated matrix contraction and collagen production in vitro. Invest Ophthalmol Vis Sci 2003; 44(3): 1104-10. [http://dx.doi.org/10.1167/iovs.02-0412] [PMID: 12601036]

[127] Wong TT, Mead AL, Khaw PT. Matrix metalloproteinase inhibition modulates postoperative scarring after experimental glaucoma filtration surgery. Invest Ophthalmol Vis Sci 2003; 44(3): 1097-103. [http://dx.doi.org/10.1167/iovs.02-0366] [PMID: 12601035]

[128] Wong TT, Mead AL, Khaw PT. Prolonged antiscarring effects of ilomastat and MMC after experimental glaucoma filtration surgery. Invest Ophthalmol Vis Sci 2005; 46(6): 2018-22. [http://dx.doi.org/10.1167/iovs.04-0820] [PMID: 15914618]

[129] Smith TP, Alshafie TA, Cruz CP, et al. Saratin, an inhibitor of collagen-platelet interaction, decreases venous anastomotic intimal hyperplasia in a canine dialysis access model. Vasc Endovascular Surg 2003; 37(4): 259-69. [http://dx.doi.org/10.1177/153857440303700405] [PMID: 12894368]

[130] Davis JA, Brown AT, Alshafie T, et al. Saratin (an inhibitor of platelet-collagen interaction) decreases platelet aggregation and homocysteinemediated postcarotid endarterectomy intimal hyperplasia in a dose-dependent manner. Am J Surg 2004; 188(6): $778-85$. [http://dx.doi.org/10.1016/j.amjsurg.2004.08.061] [PMID: 15619499]

[131] Min J, Lukowski ZL, Levine MA, et al. Prevention of ocular scarring post glaucoma filtration surgery using the inflammatory cell and platelet binding modulator saratin in a rabbit model. PLoS One 2012; 7(4): e35627. [http://dx.doi.org/10.1371/journal.pone.0035627] [PMID: 22558182]

[132] Crown J, O’Leary M. The taxanes: an update. Lancet 2000; 355(9210): 1176-8. [http://dx.doi.org/10.1016/S0140-6736(00)02074-2] [PMID: 10791395]

[133] Stahnke T, Löbler M, Kastner C, et al. Different fibroblast subpopulations of the eye: a therapeutic target to prevent postoperative fibrosis in glaucoma therapy. Exp Eye Res 2012; 100: 88-97. [http://dx.doi.org/10.1016/j.exer.2012.04.015] [PMID: 22579993]

[134] Jampel HD, Moon JI. The effect of paclitaxel powder on glaucoma filtration surgery in rabbits. J Glaucoma 1998; 7(3): 170-7. [http://dx.doi.org/10.1097/00061198-199806000-00005] [PMID: 9627856]

[135] Autiero M, Luttun A, Tjwa M, Carmeliet P. Placental growth factor and its receptor, vascular endothelial growth factor receptor-1: novel targets for stimulation of ischemic tissue revascularization and inhibition of angiogenic and inflammatory disorders. $\mathrm{J}$ Thromb Haemost 2003 ; 1(7): 1356-70. [http://dx.doi.org/10.1046/j.1538-7836.2003.00263.x] [PMID: 12871269] 
[136] Carmeliet P, Moons L, Luttun A, et al. Synergism between vascular endothelial growth factor and placental growth factor contributes to angiogenesis and plasma extravasation in pathological conditions. Nat Med 2001; 7(5): 575-83. [http://dx.doi.org/10.1038/87904] [PMID: 11329059]

[137] Luttun A, Tjwa M, Moons L, et al. Revascularization of ischemic tissues by PlGF treatment, and inhibition of tumor angiogenesis, arthritis and atherosclerosis by anti-Flt1. Nat Med 2002; 8(8): 831-40. [PMID: 12091877]

[138] Van Bergen T, Van de Veire S, Vandewalle E, Moons L, Stalmans I. Role of placental growth factor (PLGF) in wound healing after glaucoma filtration surgery. Bull Soc Belge Ophtalmol 2011; (317): 65-6. [PMID: 21560865]

[139] Van Bergen T, Jonckx B, Hollanders K, et al. Inhibition of placental growth factor improves surgical outcome of glaucoma surgery. J Cell Mol Med 2013; 17(12): 1632-43. [http://dx.doi.org/10.1111/jcmm.12151] [PMID: 24118824]

[140] Yan ZC, Bai YJ, Tian Z, et al. Anti-proliferation effects of Sirolimus sustained delivery film in rabbit glaucoma filtration surgery. Mol Vis 2011; 17: 2495-506. [PMID: 21976960]

[141] Yilmaz A, Yildirim O, Tamer L, et al. Effects of caffeic acid phenethyl ester on endotoxin-induced uveitis in rats. Curr Eye Res 2005; 30(9): 755-62. [http://dx.doi.org/10.1080/02713680590967962] [PMID: 16146921]

[142] Totan Y, Aydin E, Cekiç O, et al. Effect of caffeic acid phenethyl ester on corneal neovascularization in rats. Curr Eye Res 2001; 23(4): 291-7. [http://dx.doi.org/10.1076/ceyr.23.4.291.5453] [PMID: 11852431]

[143] Akyol S, Ugurcu V, Balci M, et al. Caffeic acid phenethyl ester: its protective role against certain major eye diseases. J Ocul Pharmacol Ther 2014; 30(9): 700-8. [http://dx.doi.org/10.1089/jop.2014.0046] [PMID: 25100535]

[144] Li N, Cui J, Duan X, Chen H, Fan F. Suppression of type I collagen expression by miR-29b via PI3K, Akt, and Sp1 pathway in human Tenon's fibroblasts. Invest Ophthalmol Vis Sci 2012; 53(3): 1670-8. [http://dx.doi.org/10.1167/iovs.11-8670] [PMID: 22297492] Accepted: August 18, 2015

(C) Masoumpour et al.; Licensee Bentham Open.

This is an open access article licensed under the terms of the Creative Commons Attribution-Non-Commercial 4.0 International Public License (CC BY-NC 4.0) (https://creativecommons.org/licenses/by-nc/4.0/legalcode), which permits unrestricted, non-commercial use, distribution and reproduction in any medium, provided the work is properly cited. 